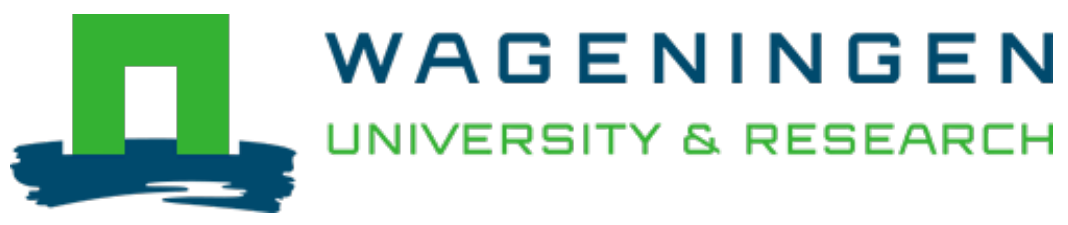

\title{
Long-term effect of composted tannery sludge on soil chemical and biological parameters
}

Environmental Science and Pollution Research

Araujo, Ademir Sergio Ferreira; Melo, Wanderley José; Araujo, Fabio Fernando; Brink, Paul J.

https://doi.org/10.1007/s11356-020-10173-9

This article is made publicly available in the institutional repository of Wageningen University and Research, under the terms of article $25 \mathrm{fa}$ of the Dutch Copyright Act, also known as the Amendment Taverne. This has been done with explicit consent by the author.

Article 25 fa states that the author of a short scientific work funded either wholly or partially by Dutch public funds is entitled to make that work publicly available for no consideration following a reasonable period of time after the work was first published, provided that clear reference is made to the source of the first publication of the work.

This publication is distributed under The Association of Universities in the Netherlands (VSNU) 'Article $25 \mathrm{fa}$ implementation' project. In this project research outputs of researchers employed by Dutch Universities that comply with the legal requirements of Article $25 \mathrm{fa}$ of the Dutch Copyright Act are distributed online and free of cost or other barriers in institutional repositories. Research outputs are distributed six months after their first online publication in the original published version and with proper attribution to the source of the original publication.

You are permitted to download and use the publication for personal purposes. All rights remain with the author(s) and / or copyright owner(s) of this work. Any use of the publication or parts of it other than authorised under article $25 \mathrm{fa}$ of the Dutch Copyright act is prohibited. Wageningen University \& Research and the author(s) of this publication shall not be held responsible or liable for any damages resulting from your (re)use of this publication.

For questions regarding the public availability of this article please contact openscience.library@wur.nl 


\title{
Long-term effect of composted tannery sludge on soil chemical and biological parameters
}

\author{
Ademir Sergio Ferreira Araujo ${ }^{1}$ - Wanderley José de Melo ${ }^{2,3}$ • Fabio Fernando Araujo ${ }^{4}$ Paul J. Van den Brink ${ }^{5,6}$
}

Received: 7 May 2020 / Accepted: 16 July 2020

(C) Springer-Verlag GmbH Germany, part of Springer Nature 2020

\begin{abstract}
Composting has been recommended as a suitable alternative for recycling wastes and could improve tannery sludge (TS) before its use. However, the long-term application of composted tannery sludge (CTS) may bring concerns about its effects on soil properties and, consequently, on plants and environment, mainly when considering $\mathrm{Cr}$ contamination. In this study, we summarize the responses of soil chemical and biological parameters in a 10-year study with yearly applications of CTS. Chemical and biological parameters were assessed in soil samples, and the multivariate analysis method principal response curve (PRC) was used to show the temporal changes in all the biological and chemical properties caused by CTS. The PRC analysis showed different long-term response patterns of chemical and biological parameters according to the rates of CTS. Interestingly, $\mathrm{Cr}$ content increased strongly in the first 5 years and only increased slightly in the following 5 years. The yearly applications of CTS changed the biological and chemical parameters of the soil, negatively and positively, respectively. Organic matter, $\mathrm{K}$ and $\mathrm{P}$, increased during the 10 years of application, while soil $\mathrm{pH}$ and $\mathrm{Cr}$ concentration increased, and soil microbial biomass and enzymes activity decreased.
\end{abstract}

Keywords Industrial waste $\cdot$ Soil quality $\cdot$ Metals $\cdot$ Environmental contamination

\section{Introduction}

The agricultural use of municipal and industrial wastes, as a potential possibility for recycling, has increased

Responsible Editor: Kitae Baek

Electronic supplementary material The online version of this article (https://doi.org/10.1007/s11356-020-10173-9) contains supplementary material, which is available to authorized users.

Ademir Sergio Ferreira Araujo

asfaruaj@yahoo.com.br

1 Soil Quality Lab., Agricultural Science Center, Federal University of Piauí, Teresina, PI, Brazil

2 School of Agricultural and Veterinarian Sciences, São Paulo State University (UNESP), Jaboticabal, SP 14884-900, Brazil

3 University of Brazil, Campus Descalvado, Hilário da Silva Passos Avenue, 950, University Park, Descalvado, SP, Brazil

4 University of West São Paulo, UNOESTE, Presidente Prudente, SP, Brazil

5 Wageningen Environmental Research, Wageningen, The Netherlands

6 Aquatic Ecology and Water Quality Management Group, Wageningen University, Wageningen, The Netherlands worldwide. For instance, municipal wastes are already recommended to be used as fertilizers in agricultural soils (Romanos et al. 2019; Kicińska et al. 2019). However, industrial wastes present some restriction for agricultural uses, mainly due to their chemical composition including some toxic metals (Miranda et al. 2019). Particularly, tannery sludge (TS), a waste generated by tannery industries, has been studied as potential waste to be applied in soils, since it has high organic matter content and contains some plant nutrients (Araújo et al. 2013). However, TS also presents high content of $\mathrm{Cr}$ that can contaminate the soil and plants. For example, the presence of $\mathrm{Cr}$ in soil has affected rhizobia that promote the biological $\mathrm{N}$ fixation in legumes (Miranda et al. 2014). In maize and cowpea, $\mathrm{Cr}$ has been translocated to shoot and grains (Sousa et al. 2018) and can bring some health issues, such as cancer and allergic dermatitis in humans (Scragg 2006).

Some alternative methods for recycling TS, such as composting, have been recommended before its application in soil (Silva et al. 2010; Santos et al. 2011). Indeed, composting is an effective process for organic residues decomposition, improving their biological, chemical, and physical quality (Singh et al. 2011). On the one hand, composting does not decrease $\mathrm{Cr}$ content since the process 
does not remove or degrade $\mathrm{Cr}$ from the waste (Santos et al. 2011). On the other hand, the increase in soil organic matter content, after application of compost, can improve the soil quality and ameliorate the effect of $\mathrm{Cr}$ on soil properties (Oliveira et al. 2015). For instance, the application of composted tannery sludge (CTS) for years increased the soil organic matter and the levels of plant nutrients. However, the concentration of $\mathrm{Cr}$ also increased after the application of CTS (Araujo et al. 2013).

The positive shifting in the soil chemical parameters after CTS application is important since the chemical elements improve the soil fertility and provide nutrients to plants (Schjoerring et al. 2019). However, the increases in some chemical parameters, such as soil organic matter (SOM) and $\mathrm{Cr}$ concentration, affect the soil biological properties over time (Sousa et al. 2017). Biological properties are important to the suitable soil functioning, as they regulate several processes in soil, such as organic matter dynamic and availability of nutrients (Cardoso et al. 2013). Important biological parameters like soil microbial biomass (SMB) and enzymes are quite sensitive to soil disturbance after application of wastes (Araujo et al. 2010). Some previous studies have reported the long-term effect of municipal waste on chemical and biological properties (Bastida et al. 2008; Walia and Goyal 2010; Srivastava et al. 2016). So far, there are no studies evaluating the effect of CTS on soil chemical and biological parameters in the long term, i.e., longer than years.

Here, we summarize the results of a long-term experiment, i.e., over 10 years, evaluating the effect of CTS on chemical and biological soil parameters. The main research question is how the chemical and microbial properties change during 10 years of yearly applications of CTS. We assessed the annual and cumulative responses of chemical and biological parameters to 10 yearly applications of CTS. In addition, we used the principal response curve (PRC), a multivariate method based on redundancy analysis, to verify the treatment effects through 10 years of application (Van den Brink and Ter Braak 1998, 1999).

\section{Material and methods}

\section{Experimental site}

The long-term experiment was conducted on an experimental field located at the Federal University of Piauí, Brazil. The soil is a "fluvent" soil (USDA Soil Taxonomy) presenting 100$\mathrm{g} / \mathrm{kg}$ clay, $282-\mathrm{g} / \mathrm{kg}$ silt, and $618 \mathrm{-g} / \mathrm{kg}$ sand. CTS was obtained by composting tannery sludge (a mixing of TS, sugarcane bagasse, and manure; 1:3:1 v:v:v) during 3 months. The average chemical properties of CTS were (USEPA 1986) $\mathrm{pH}=$ 8.5 , organic $\mathrm{C}=187 \mathrm{~g} / \mathrm{kg}, \mathrm{N}=1.7 \mathrm{~g} / \mathrm{kg}, \mathrm{P}=4.0 \mathrm{~g} / \mathrm{kg}, \mathrm{K}=3.3$ $\mathrm{g} / \mathrm{kg}, \mathrm{Ca}=95.3 \mathrm{~g} / \mathrm{kg}, \mathrm{Mg}=6.8 \mathrm{~g} / \mathrm{kg}, \mathrm{S}=9.4 \mathrm{~g} / \mathrm{kg}, \mathrm{Cu}=17.8$ $\mathrm{mg} / \mathrm{kg}, \mathrm{Ni}=21.9 \mathrm{mg} / \mathrm{kg}, \mathrm{Cd}=2.9 \mathrm{mg} / \mathrm{kg}, \mathrm{Pb}=12.6 \mathrm{mg} / \mathrm{kg}$, and $\mathrm{Cr}=1815 \mathrm{mg} / \mathrm{kg}$. The same CTS was applied in all years, and its quality, regarding to chemical composition, was assured regularly by laboratory analysis.

The experiment was started in 2009 by the inputs of CTS at the following rates: 0 (control), 2.5, 5, 10, and 20 t/ha. From the beginning of the experiment until 2019, we sowed cowpea (Vigna unguiculata) in experimental plots of $20 \mathrm{~m}^{2}$. Every year, before cowpea sowing, CTS was applied on the soil and incorporated into the $0.2-\mathrm{m}$ layer. At 45 th day from the application of CTS, soils were sampled using four subsamples per plot, at 0 - to $0.2-\mathrm{m}$ depth. The samples were subsequently sieved $(2 \mathrm{~mm})$ and stored at $4{ }^{\circ} \mathrm{C}$.

\section{Chemical and biological parameters}

Soil $\mathrm{pH}, \mathrm{Ca}, \mathrm{K}$, and $\mathrm{P}$ were analyzed according to Donagema et al. (2011). The electric conductivity (EC) was estimated through the methodology proposed by Richards (1954). Total organic C (TOC) was estimated using the wet combustion method (Yeomans and Bremner 1988), while the total $\mathrm{Cr}$ concentration in soil was determined by atomic absorption spectrophotometry (USEPA 1986).

Soil microbial biomass C (MBC) and N (MBN) were estimated by chloroform fumigation-extraction method according to Vance et al. (1987) and Brookes et al. (1985), respectively.
Table 1 Soil $\mathrm{pH}$, total organic $\mathrm{C}$ $\left(\mathrm{g} \mathrm{kg}^{-1}\right), \mathrm{Ca}\left(\mathrm{cmol}_{\mathrm{c}} \mathrm{kg}^{-1}\right)$, and electric conductivity $\left(\mathrm{dS} \mathrm{m}^{-1}\right)$ in soil after 10 years of CTS application as well as the preceding years (year 1-9)

\begin{tabular}{|c|c|c|c|c|c|c|c|c|}
\hline \multirow{2}{*}{$\begin{array}{l}\text { CTS } \\
\text { (t/ha) }\end{array}$} & \multicolumn{2}{|l|}{ Soil pH } & \multicolumn{2}{|c|}{ Total organic $\mathrm{C}$} & \multicolumn{2}{|l|}{ Ca content } & \multicolumn{2}{|c|}{ Electric conductivity } \\
\hline & 10th year & Year 1-9 & 10 th year & Year 1-9 & 10 th year & Year 1-9 & 10 th year & Year 1-9 \\
\hline 0 & 6.3 & 6.2 & 8.8 & 9.0 & 0.9 & 0.8 & 0.25 & 0.27 \\
\hline 2.5 & 7.8 & 7.6 & 21.5 & 21.0 & 1.9 & 1.0 & 1.35 & 0.90 \\
\hline 5 & 8.1 & 8.0 & 26.7 & 26.1 & 2.2 & 2.1 & 1.70 & 1.13 \\
\hline 10 & 8.6 & 8.5 & 34.7 & 33.8 & 2.8 & 2.7 & 2.81 & 1.90 \\
\hline 20 & 8.8 & 8.7 & 42.9 & 41.8 & 3.9 & 3.7 & 3.89 & 2.45 \\
\hline NOEC & 0 & $2.5 ; 0$ & 0 & 0 & 0 & 0 & 0 & 0 \\
\hline
\end{tabular}

A more detailed overview on the NOECs at the different years is referred to Table S1 
Table $2 \mathrm{~K}\left(\mathrm{mg} \mathrm{kg}^{-1}\right), \mathrm{P}\left(\mathrm{mg} \mathrm{kg}^{-1}\right)$, and $\mathrm{Cr}\left(\mathrm{mg} \mathrm{kg}^{-1}\right)$ in soil after 10 years of CTS application as well as the preceding years (year 1-9)

\begin{tabular}{|c|c|c|c|c|c|c|}
\hline \multirow{2}{*}{$\begin{array}{l}\text { CTS } \\
\text { (t/ha) }\end{array}$} & \multicolumn{2}{|l|}{$\mathrm{K}$ content } & \multicolumn{2}{|l|}{$\mathrm{P}$ content } & \multicolumn{2}{|l|}{ Cr content } \\
\hline & 10th year & Year 1-9 & 10th year & Year 1-9 & 10th year & Year 1-9 \\
\hline 0 & 29.6 & 29.6 & 2.9 & 2.8 & 2.6 & 2.5 \\
\hline 2.5 & 58.9 & 57.8 & 5.3 & 5.1 & 10.9 & 10.0 \\
\hline 5 & 58.4 & 57.2 & 8.0 & 7.7 & 67.1 & 56.5 \\
\hline 10 & 61.6 & 60.7 & 7.8 & 7.6 & 85.5 & 72.5 \\
\hline 20 & 73.4 & 72.3 & 12.6 & 12.1 & 134.0 & 118.3 \\
\hline NOEC & 0 & $2.5 ; 0$ & 0 & $2.5 ; 0$ & 0 & $2.5 ; 0$ \\
\hline
\end{tabular}

A more detailed overview on the NOECs at the different years is referred to Table S1
Soil basal respiration (BR) was estimated through the method of $\mathrm{CO}_{2}$ evolution proposed by Alef and Nannipieri (1995). The $\mathrm{BR} / \mathrm{MBC}$ is the ratio between $\mathrm{BR}$ and $\mathrm{MBC}\left(\mathrm{mg} \mathrm{CO} \mathrm{CO}_{2}\right.$ $\left.\mathrm{kg}^{-1} \mathrm{MBC} \mathrm{d}{ }^{-1}\right)$. The $\mathrm{MBC} / \mathrm{TOC}$ is the ratio between $\mathrm{MBC}$ to TOC (\%). Dehydrogenase (DHA) was estimated through the method proposed by Casida et al. (1965). Fluorescein diacetate (FDA) hydrolysis was estimated according to Schnurer and Rosswall (1982).

\section{Statistical analysis}

No observed effect concentrations (NOECs) were calculated for all CTS rates and biological and chemical variables separately. The effects were considered consistent when they showed statistically significant deviations pointing in the same direction for at least two consecutive sampling years. The NOEC calculations were performed using the Williams test, which assumes a monotonic increasing effect with increasing exposure dose (Williams 1972). The Williams tests were performed with the Community Analysis computer program, version 4.3.05, using a significance level of 0.05 (Hommen et al. 1994).

PRC was used to show the temporal changes in all the biological and chemical parameters influenced by CTS rates in comparison with the control soil (without CTS) into one diagram (i.e., reduce the effects of all treatments at all years on all properties into one dimension) and also to assess the affinity of each property to the indicated differences between the treatments and the control. Monte Carlo permutation tests were used to verify if the PRC diagrams are significant through of the $F$ test (Van den Brink and Ter Braak 1999). After the first PRC, a second PRC was built using the remaining variance, which was also evaluated on its significance.

The effects of treatments on the biological and chemical parameters were evaluated through Monte Carlo permutation tests under the redundancy analysis option. For each sampling year, Monte Carlo permutation tests were performed by testing the replicates of each treatment against those of the controls, to evaluate the significance of each treatment in each time. All multivariate analyses were performed using the CANOCO 5 program (Ter Braak and Šmilauer 2018).

\section{Results and discussion}

The chemical and biological parameters were positive and negatively influenced by the long-term application of CTS, respectively. All chemical variables increased significantly due to the 10 yearly applications of CTS (Tables 1 and 2; Table S1). Soil pH, K, Ca, TOC, P, and EC increased about $0.5,2.5,3,4,5$, and 9 times after the application of $20 \mathrm{t} / \mathrm{ha}$,
Table 3 Microbial biomass $\mathrm{C}$ (mg C kg-1 soil), $\mathrm{N}$ (mg N kg soil), and the microbial $\mathrm{C}: \mathrm{N}$ ratio in soil after 10 years of CTS application as well as the preceding years (year 1-9)

\begin{tabular}{|c|c|c|c|c|c|c|}
\hline \multirow{2}{*}{$\begin{array}{l}\text { CTS } \\
\text { (t/ha) }\end{array}$} & \multicolumn{2}{|c|}{ Microbial biomass $\mathrm{C}$} & \multicolumn{2}{|c|}{ Microbial biomass $\mathrm{N}$} & \multicolumn{2}{|c|}{ Microbial biomass C:N } \\
\hline & 10th year & Year 1-9 & 10th year & Year $1-9$ & 10th year & Year 1-9 \\
\hline 0 & 124 & 138 & 25 & 30 & 5.9 & 5.2 \\
\hline 2.5 & 108 & 135 & 19 & 27 & 5.2 & 5.1 \\
\hline 5 & 88 & 124 & 16 & 22 & 5.4 & 4.9 \\
\hline 10 & 71 & 121 & 12 & 23 & 5.9 & 5.3 \\
\hline 20 & 73 & 104 & 11 & 18 & 6.3 & 5.9 \\
\hline NOEC & 0 & $20 ; 10 ; 5 ; 2.5$ & 2.5 & $5 ; 2.5 ; 0$ & 20 & $20 ; 10 ; 5 ; 2.5 ; 0$ \\
\hline
\end{tabular}

A more detailed overview on the NOECs at the different years is referred to Table S2 
Table 4 Dehydrogenase activity (mg TTF $\mathrm{g}^{-1}$ soil) and hydrolysis of fluorescein diacetate (mg FDA g ${ }^{-1}$ soil) in soil after 10 years of CTS application as well as the preceding years (year 1-9)

\begin{tabular}{llllll}
\hline CTS & \multicolumn{2}{l}{ Dehydrogenase } & & \multicolumn{2}{l}{ Fluorescein diacetate } \\
\cline { 2 - 3 } \cline { 5 - 6 } (t/ha) & 10 th year & Year 1-9 & & 10 th year & Year 1-9 \\
\hline 0 & $2.1^{\mathrm{a}}$ & $2.0^{\mathrm{a}}$ & & $20.3^{\mathrm{a}}$ & $18.2^{\mathrm{a}}$ \\
2.5 & $1.6^{\mathrm{b}}$ & $1.8^{\mathrm{a}}$ & & $13.0^{\mathrm{b}}$ & $17.4^{\mathrm{a}}$ \\
5 & $0.5^{\mathrm{b}}$ & $1.2^{\mathrm{b}}$ & & $12.6^{\mathrm{b}}$ & $18.7^{\mathrm{a}}$ \\
10 & $0.4^{\mathrm{c}}$ & $1.0^{\mathrm{b}}$ & & $11.4^{\mathrm{b}}$ & $19.3^{\mathrm{a}}$ \\
20 & $0.1^{\mathrm{c}}$ & $0.7^{\mathrm{c}}$ & & $7.5^{\mathrm{c}}$ & $12.6^{\mathrm{b}}$ \\
NOEC & 0 & $2.5 ; 0$ & & 0 & $20 ; 5 ; 0$ \\
\hline
\end{tabular}

A more detailed overview on the NOECs at the different years is referred to Table S2

respectively. Markedly, the $\mathrm{Cr}$ concentration in the highest treatment increased 50 times compared with the concentration in the control.

The long-term application of CTS increased the values of chemical parameters since this waste has a high organic matter content and concentrations of chemical elements, mainly carbonates, hydroxides, and chromium. On the one hand, the increase in the concentrations of $\mathrm{K}, \mathrm{Ca}, \mathrm{TOC}$, and $\mathrm{P}$ is interesting because these parameters improve the soil fertility and increase the supply of nutrients to the plant (Cardoso et al. 2013). Indeed, the concentrations of $\mathrm{K}, \mathrm{Ca}, \mathrm{TOC}$, and $\mathrm{P}$ are considered high for sandy soils in Brazil (Novais et al. 2007). On the other hand, the increase in the $\mathrm{pH}$ and $\mathrm{Cr}$ values can negatively affect the soil and plants. For example, the high soil $\mathrm{pH}$ values found in the treatments can decrease the availability of some important plant nutrients, such as N, S, P, and micronutrients (Havlin et al. 2004). According to Jensen and Thomas (2010), most of the plant nutrients are optimally available at a pH between 6 and 7, and this range is compatible to plant root growth. However, most of the nutrients (especially micronutrients) tend to be less available when soil $\mathrm{pH}$ is above 7.5 . Regarding to $\mathrm{Cr}$, the values increased significantly over the 10 years, resulting from the high $\mathrm{Cr}$ content in CTS, and it can negatively affect the soil biological properties (Wyszkowska et al. 2001).

Indeed, MBC and MBN decreased after the application of CTS (Table 3; Table S2). In the 10th year, the highest values of $\mathrm{MBC}$ and $\mathrm{MBN}$ were found in unamended soils, while the lowest values were found in the treatments with application of 10 and $20 \mathrm{t} /$ ha CTS. In the years 0 through 9 , the highest values of $\mathrm{MBC}$ and $\mathrm{MBN}$ were found in the control soils and the lowest CTS treatment, while the lowest values were found in the highest CTS treatment. Interestingly, the $\mathrm{MBC}: \mathrm{MBN}$ ratio did not vary between treatments after 10 years of CTS application.

These results show that the long-term use of CTS increases the soil $\mathrm{pH}(38 \%)$, the EC (1456\%), and the $\mathrm{Cr}$ concentration $(5054 \%)$, which may have negatively influenced the soil microbial biomass. Soil MBC and MBN decreased about 25 and $40 \%$, respectively, in the highest CTS treatment. Previous studies have reported increases in soil pH (43\%; Sawada et al. 2009), electric conductivity (100\%; Elmajdoub and Marschner 2015), and Cr (5000\%; Sousa et al. 2017) promoting decreases of soil microbial biomass. Soil $\mathrm{pH}$ controls microbial mechanisms of $\mathrm{C}$ accumulation and the increase in soil pH leads to C loss by microbial biomass (Malik et al. 2018), while high EC promotes an influx of salty water and decreases the content of soil microbial biomass (Rietz and Haynes 2003). As the main chemical element increased markedly in the treatment with CTS, Cr may have contributed to the decrease of soil microbial biomass due to the oxidative damage it causes to microbes (Ackerley et al. 2006). The results also showed that, although soil microbial biomass decreased with increasing CTS treatments, the microbial $\mathrm{C}: \mathrm{N}$ ratios did not vary, which can indicate that the long-term application of CTS does not influence the stoichiometry of soil microbial biomass. This finding is important as any change in stoichiometry of soil microbial biomass, due to the soil disturbance, could promote significant impacts on $\mathrm{N}$ cycling (Zhaolei et al. 2019).

Similarly, the activity of enzymes decreased after the application of CTS (Table 4; Table S2). On the 10th year of
Table 5 Soil basal respiration (mg CO $2 \mathrm{~kg}^{-1}$ soil), MBC/TOC (\%), and $\mathrm{BR} / \mathrm{MBC}\left(\mathrm{mg} \mathrm{CO} \mathrm{kg}^{-1}\right.$ $\mathrm{MBC}$ ) in soil after 10 years of CTS application

\begin{tabular}{|c|c|c|c|c|c|c|}
\hline \multirow{2}{*}{$\begin{array}{l}\text { CTS } \\
(\mathrm{t} / \mathrm{ha})\end{array}$} & \multicolumn{2}{|c|}{ Soil basal respiration } & \multicolumn{2}{|c|}{$\mathrm{MBC} / \mathrm{TOC}$} & \multicolumn{2}{|l|}{$\mathrm{BR} / \mathrm{MBC}$} \\
\hline & 10th year & Year 1-9 & 10th year & Year 1-9 & 10th year & Year 1-9 \\
\hline 0 & 36.2 & 43.1 & 1.8 & 1.4 & 0.29 & 0.31 \\
\hline 2.5 & 42.5 & 46.4 & 0.4 & 0.7 & 0.39 & 0.43 \\
\hline 5 & 43.7 & 47.8 & 0.3 & 0.5 & 0.49 & 0.48 \\
\hline 10 & 46.7 & 48.9 & 0.1 & 0.4 & 0.66 & 0.55 \\
\hline 20 & 50.5 & 55.3 & 0.1 & 0.3 & 0.69 & 0.61 \\
\hline NOEC & 0 & $20 ; 10 ; 5 ; 2.5 ; 0$ & 0 & $0 ; 2.5$ & 0 & $20 ; 10 ; 5 ; 2.5 ; 0$ \\
\hline
\end{tabular}

A more detailed overview on the NOECs at the different years is referred to Table S2 


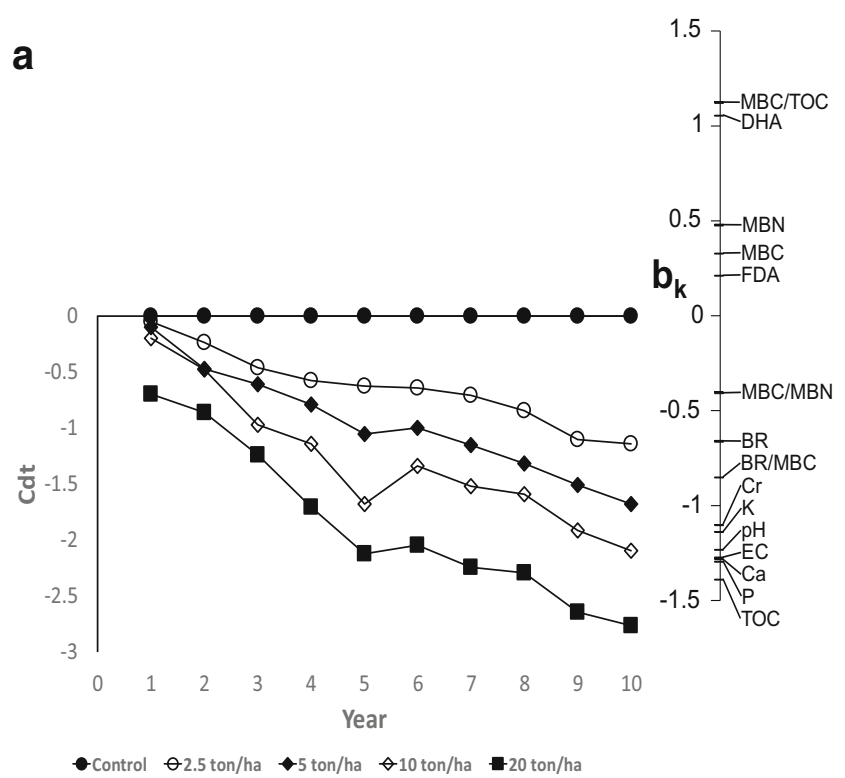

b

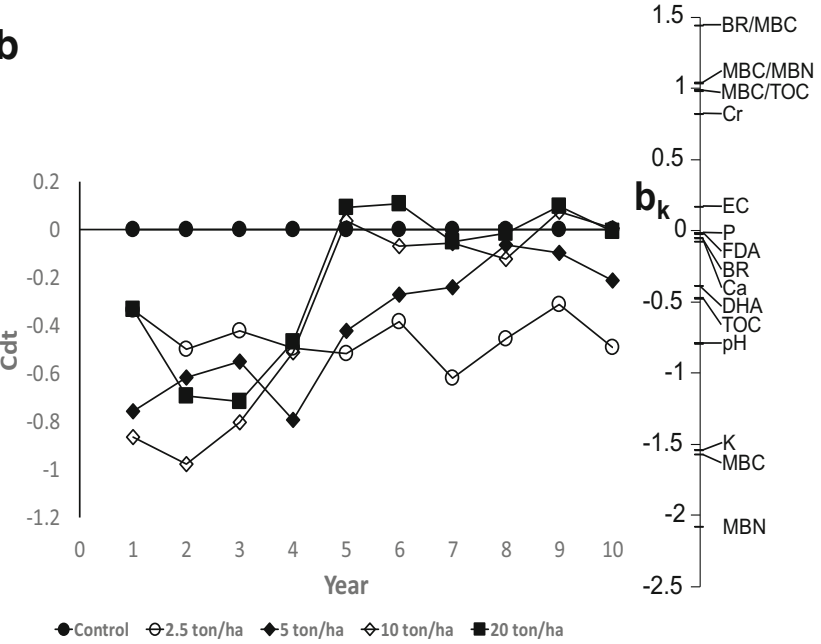

Fig. 1 First (a) and second (b) principal response curves indicating the effects of composted tannery sludge on soil chemical and microbial properties. Of all variance, $27 \%$ could be attributed to sampling date; this is displayed on the horizontal axis. $61 \%$ percent of all variance could be attributed to treatment, the remaining variance $(12 \%)$ is between replicate variations. Of the treatment variance, $73 \%$ is displayed on the vertical axis of the first PRC (a), and another $10 \%$ on the vertical axis of the second PRC (b). The lines represent the course of the treatment levels in time. The species weight $\left(b_{\mathrm{k}}\right)$ can be interpreted as the affinity of the properties with the principal response curves $\left(c_{\mathrm{dt}}\right)$. The treatment explained a significant part of the total variance, of which also a significant part is displayed in the first and second PRC $(p=0.002$, Monte Carlo permutation test with permuting whole time series only). The third and fourth PRC did not show significant variation, displaying 7and 3\%, respectively $(p<0.005)$. They are left out from the interpretation for clarity as they do not display a large portion of the overall variation

application, the highest values of enzymes were found in the control, unamended soils. The values of dehydrogenase were lower in the 10 and 20 t/ha CTS treatments, while the hydrolysis of FDA decreased in the highest CTS treatment. In the accumulative years, the highest value of dehydrogenase was found in control soil, while the values of FDA did not vary up to $10 \mathrm{tha}^{-1} \mathrm{CTS}$. On the 10th year, the lowest values of enzymes were found in the highest CTS treatment. Dehydrogenase and FDA are indicators of microbial activity (Salazar et al. 2011) and highly sensitive to high soil pH, salinity, and $\mathrm{Cr}$ concentrations (Brzezińska et al. 2001; Mahajan et al. 2015). For example, Brzezińska et al. (2001) found the $\mathrm{pH}$ range of 6.6 to 7.2 as suitable for higher dehydrogenase activity. Increases in salinity will increase the osmotic stress on soil microorganisms (Frankenbeger and Bingham 1982). Thus, Mahajan et al. (2015) found a significant decrease in the activity of enzymes, such as dehydrogenase, when the EC was higher than $2.0 \mathrm{dS} \mathrm{m}^{-1}$. In our study, the highest CTS rate increased the EC to values of $2.45 \mathrm{dS}$ $\mathrm{m}^{-1}$ which explains the decrease in the enzyme activities. The excess of $\mathrm{Cr}$ in soil can disturb the homeostatic metabolism of microorganisms which negatively affects the enzymatic activity (Wolinska and Stepniewska 2012).

In contrast to soil microbial biomass, basal respiration and $\mathrm{BR} / \mathrm{MBC}$ increased after the applications of CTS (Table 5; Table S2), and the highest values of these parameters were found in the highest CTS treatment. The values of MBC/TOC decreased after the applications of CTS, as compared with control soil (Table 5). The highest MBC/TOC ratio was observed in the control soils, while the values did not differ between CTS treatments.

Although higher basal respiration indicates an increased biological activity, the concomitant increase in $\mathrm{BR} / \mathrm{MBC}$ means that this respiration is produced by the losses of $\mathrm{C}$ from microbial biomass. Thus, these results indicate that CTS negatively affected the soil microbial biomass and promoted $\mathrm{C}$ losses through respiration. Previous studies have found increases in BR/MBC after long-term application of metal-rich wastes, such as municipal (Leita et al. 1999) and industrial wastes (Boechat et al. 2012). For example, Leita et al. (1999) assessed the long-term effects (12 years) of composted municipal waste on soil biological parameters and found a significant increase in the values of $\mathrm{BR} / \mathrm{MBC}$ in soil with an application of $1500 \mathrm{~kg} \mathrm{ha}^{-1}$ which added 2.9, 81.4, 30.7, 83.7, and $129 \mathrm{mg} \mathrm{kg}^{-1}$ of $\mathrm{Cd}, \mathrm{Cu}, \mathrm{Ni}, \mathrm{Pb}$, and $\mathrm{Zn}$, respectively.

On the other hand, the lowest values of MBC/TOC in the highest CTS treatment suggest that long-term applications of CTS increase the instability of soil organic matter and, thus, this fraction of the soil is more susceptible to losses. In addition, soils with higher values of MBC/TOC present better quality (Kaschuk et al. 2010). Thus, our results suggest that the application of CTS contributed for decreasing soil quality.

The PRC analysis indicated that CTS applied over 10 years significantly influenced the chemical and biological parameters (Fig. 1; Table S3), showing that the first and second PRC were significant. The first PRC shows an increasing deviation from the control in time for all treatments with increasing differences with increasing CTS rates. Monte Carlo 
Fig. 2 Diagram of the long-term effect of CTS application on soil properties

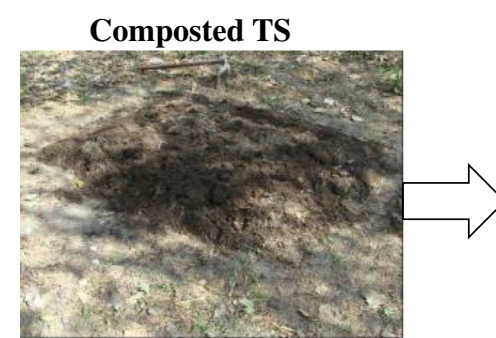

Positive properties

High content of organic $C$, $\mathrm{N}, \mathrm{P}, \mathrm{S}$ and micronutrients

Negative properties High content of $\mathbf{C r}$, salts and hydroxides

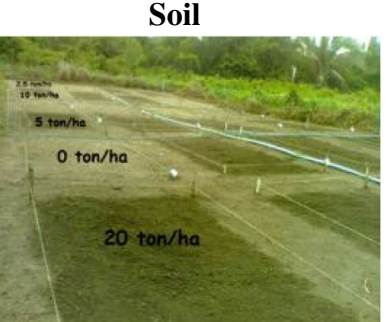

Positive impacts Increased TOC, $\mathrm{pH}$ and $\mathrm{K}$

Negative impacts Increased $\mathrm{Cr}$ accumulation Decreased MBC, MBN, $\mathrm{MBC} / \mathrm{TOC}$ and DHA
Positive implications

Chelation of $\mathbf{C r}$ Increased crop yield

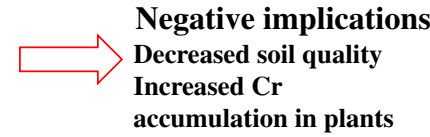

permutation tests show that all treatment-year combinations are significantly different from their control except for the lowest CTS treatment in year 1 (Table S3). MBC/TOC and DHA had a positive weight with the diagram, $\mathrm{Cr}, \mathrm{K}, \mathrm{pH}, \mathrm{EC}$, $\mathrm{Ca}, \mathrm{P}$, and TOC had a negative weight, while the remaining parameters had a low weight. The second PRC makes a distinction between parameters which show a larger and smaller response as indicated by the first PRC in the first few years. For instance, MBC/TOC has a positive weight with both diagrams, so its real response is close to the sum of both PRCs which results in a larger initial response than indicated in the first PRC alone (see right upper quadrant in Fig. S1). BR/ $\mathrm{MBC}$ has a negative weight with the first PRC and a positive with the second that resulted in a delayed increase of this property compared with the response given in the first PRC (see Fig. S1). Figure S1 shows the weight of all properties with both PRCs with some of the resulting response patterns. For instance, the indicated pattern of BR/MBC response is the opposite of the one given in the lower right quadrant. By including the second PRC, a more detailed categorization in response patterns is obtained, where properties with a high (positive or negative) weight in the first PRC show an increasing difference to the control in time, while properties with positive and negative weight in the first and second PRCs (or vice versa), respectively, show a rapid difference with the control but a stabilization of this difference after 5 years. Properties with a positive or negative weight with both PRCs show a large initial difference (Fig. S1). An exact combined interpretation of the first and second PRC is referred to Van den Brink and Ter Braak (1998).

The PRC analysis (two dimensional) has shown different response patterns of chemical and biological parameters to the different CTS treatments over 10 years (Fig. S1). The diagram shows that TOC, $\mathrm{pH}$, and $\mathrm{K}$ increased due to the 10 yearly applications of CTS. In contrast, MBC, MBN, MBC/TOC, and DHA decreased after the applications of CTS. Cr content, $\mathrm{BR} / \mathrm{MBC}$, and $\mathrm{MBC} / \mathrm{MBN}$ increased strongly up to 5 years and then there was a slight increase between 5 and 10 years.
This PRC confirms a positive and direct effect of CTS on TOC, $\mathrm{pH}$, and $\mathrm{K}$ and negative effects on soil microbial biomass and enzymes (Fig. 2). These results indicate that the long-term application of CTS increases the status of soil organic matter and some chemical parameters significantly (Oliveira et al. 2015) which may result in a consequent increase in crop yield (Sousa et al. 2017). On the other hand, the long-term application of CTS will promote the accumulation of $\mathrm{Cr}$ in roots, shoots, and grains of cowpea to concentrations above the limits proposed by Brazilian regulations (Sousa et al. 2017). However, the increase and stabilization of soil organic matter can contribute to the chelation of $\mathrm{Cr}$, making it less bioavailable (Oliveira et al. 2015). It could explain why $\mathrm{Cr}$ content increased strongly up to 5 years and slower after this period up to 10 years. On the other hand, the observed decrease in soil microbial biomass and enzymes contributes to a decreasing soil quality (Kaschuk et al. 2010).

\section{Conclusion}

This study showed the response of soil biological and chemical properties to yearly applications of composted tannery sludge for 10 years. The continuous and permanent application of CTS negatively changed the microbial biomass while positively influenced the chemical properties of the soil. Regarding to chemical properties, the positive effects were the increases of organic matter and some important chemical elements, such as $\mathrm{Ca}, \mathrm{K}$, and P. However, the negative effects were the increases in the soil $\mathrm{pH}$ and $\mathrm{Cr}$ concentration. In addition, the application of CTS decreased the soil microbial biomass and enzyme activity. This long-term study has shown that, in a Cr-contaminated tannery sludge, composting is not enough to detoxify the waste and its application brings important issues regarding to soil and plant contamination by $\mathrm{Cr}$. Thus, this specific CTS cannot be indicated as suitable for agricultural use in its current form. On the other hand, some studies are being conducted to evaluate the use of microbes 
and plants in bio- and phytoremediation of CTS-contaminated sites. In addition, further studies should be performed in order to eliminate or lower the bioavailability of $\mathrm{Cr}$ from tannery sludge before its processing by composting.

Funding information This study was funded by Conselho Nacional de Desenvolvimento Científico e Tecnológico - CNPq (grant 305069/20181). Ademir Sergio Ferreira de Araujo and Wanderley José de Melo thank $\mathrm{CNPq}$ for their fellowship of research.

\section{Compliance with ethical standards}

Conflict of interest The authors declare that they have no conflict of interest.

Ethical approval This article does not contain any studies with human participants or animals performed by any of the authors.

\section{References}

Ackerley DF, Barak Y, Lynch SV, Curtin J, Matin A (2006) Effect of chromate stress on Escherichia coli K-12. J Bacteriol 188:33713381

Alef K, Nannipieri P (1995) Methods in soil microbiology and biochemistry. Academic, New York

Araújo ASF, Silva MDM, Leite LFC, Araujo FF, Dias NS (2013) Soil $\mathrm{pH}$, electric conductivity and organic matter after three years of consecutive applications of composted tannery sludge. African J Agric Res 8:1204-1208

Bastida F, Kandeler E, Hernández T, García C (2008) Long-term effect of municipal solid waste amendment on microbial abundance and humus-associated enzyme activities under semiarid conditions. Microb Ecol 55:651-661

Boechat CL, Santos JAG, Accioly AMA, Bomfim MR, Santos AC (2012) Industrial and urban organic wastes increase soil microbial activity and biomass. Rev Bras Ci Solo 36:1629-1636

Brookes PC, Landman A, Pruden G, Jenkinson DS (1985) Chloroform fumigation and the release of soil nitrogen, a rapid direct extraction method to measure microbial biomass nitrogen in soil. Soil Biol Biochem 17:837-842

Brzezińska M, Stępniewski W, Stępniewska Z, Przywara G (2001) Effect of oxygen deficiency on soil dehydrogenase activity in a pot experiment with triticale cv. Jago vegetation. Int Agrophys 15:145149

Cardoso EJBN, Vasconcellos RLF, Bini D, Miyauchi MYH, Santos CA, Alves PRL, Paula AM, Nakatani AS, Pereira JM, Nogueira MA (2013) Soil health: looking for suitable indicators. What should be considered to assess the effects of use and management on soil health? Sci Agric 70:274-289

Casida LE, Klein DA, Santoro T (1965) Soil dehydrogenase activity. Soil Sci 98:371-376

Donagema GK, Campos DVB, Calderano SB, Teixeira WG, Viana JHM (2011) Manual de métodos de análise de solo, 2nd edn. Embrapa Solos, Rio de Janeiro

Elmajdoub B, Marschner P (2015) Response of microbial activity and biomass to soil salinity when supplied with glucose and cellulose. J Soil Sci Pl Nutrit 15:816-832

Frankenbeger WT, Bingham FT (1982) Influence of salinity on soil enzyme activities. Soil Sci Soc Am J 46:1173-1177

Havlin JL, Tisdale SL, Nelson WL, Beaton JD (2004) Soil Fertility and Fertilizers: An Introduction to Nutrient Management (7th Edition) $528 \mathrm{p}$.
Hommen U, Düllmer U, Vith D (1994) A computer program to evaluate plankton data from freshwater field tests. In: Hill IR, Heimbach F, Leeuwangh P, Matthiesen P (eds) Freshwater Field Tests for Hazard Assessment of Chemicals. Lewis Publishers, Baca Raton, pp 503513

Jensen D, Thomas L (2010) Soil pH and the availability of plant nutrients. IPNI Plant Nutrition Today, No. 2.

Kaschuk G, Alberton O, Hungria M (2010) Three decades of soil microbial biomass studies in Brazilian ecosystems: lessons learned about soil quality and indications for improving sustainability. Soil Biol Biochem 42:1-13

Kicińska A, Gucwa J, Kosa-Burda B (2019) Evaluating potential for using municipal sewage sludge in the rehabilitation of ground degraded by the sodium processing industry. Bull Environ Contam Toxicol 102:399-406

Leita L, De Nobili M, Mondini C, Muhlbachova G, Marchiol L, Bragato G, Contin M (1999) Influence of inorganic and organic fertilization on soil microbial biomass, metabolic quotient and heavy metal bioavailability. Biol Fert Soils 28:371-376

Mahajan GR, Manjunath BL, Latare AM, D'Souza R, Vishwakarma S, Singh NP (2015) Microbial and enzyme activities and carbon stock in unique acid coastal saline soils of Goa. Proc Natl Acad Sci Sect B Biol Sci 7

Malik AA, Puissant J, Buckeridge KM, Goodall T, Jehmlich N, Chowdhury S, Gweon HS, Peyton JM, Mason KE, van Agtmaal M, Blaud A, Clark IM, Whitaker J, Pywell RF, Ostle N, Gleixner G, Griffith RI (2018) Land use driven change in soil pH affects microbial carbon cycling processes. Nat Commun 9:3591

Miranda ARL, Araujo ASF, Nunes LAPL, Oliveira MLJ, Melo WJ (2014) Growth and nodulation of cowpea after 5 years of consecutive composted tannery sludge amendment. Spanish J Agric Res 12: $1175-1179$

Miranda ARL, Mendes LW, Lemos LN, Antunes JEL, Amorim MR, Melo VMM, Melo WJ, van Den Brink PJ, Araújo ASF (2019) Dynamics of archaeal community in soil with application of composted tannery sludge. Sci Rep 9:e7347

Novais RF, Alvarez VH, Barros NF, Fontes RL, Cantarutti RB, Neves JCL (2007) Fertilidade do Solo. Sociedade Brasileira de Ciencia do Solo, 562p.

Oliveira MLJ, Araújo ASF, Melo WJ (2015) Chromium in soil organic matter and cowpea after four consecutive annual applications of composted tannery sludge. Rev Bras Ci Solo 39:297-302

Richards LA (1954) Diagnosis improvements of saline and alkaline soils. Department of Agriculture, Washington, D C, 160p

Rietz DN, Haynes RJ (2003) Effects of irrigation induced salinity and sodicity on soil microbial activity. Soil Biol Biochem 35:845-854

Romanos D, Nemer N, Khairallah Y, Saab MTA (2019) Assessing the quality of sewage sludge as an agricultural soil amendment in Mediterranean habitats. Int J Recycl Org Waste Agricult 8:377-383

Salazar S, Sanchez L, Alvarez J, Valverde A, Galindo P, Igual J, Peix A, Santa Regina I (2011) Correlation among soil enzyme activities under different forest system management practices. Ecol Engin 37:11231131

Santos JA, Nunes LAPL, Melo WJ, Araújo ASF (2011) Tannery sludge compost amendment rates on soil microbial biomass of two different soils. Euro J Soil Biol 47:146-151

Sawada K, Funakawa S, Kosaki T (2009) Different effects of pH on microbial biomass carbon and metabolic quotients by fumigationextraction and substrate- induced respiration methods in soils under different climatic conditions. Soil Sci Plant Nutr, 55:363-374

Schjoerring JK, Cakmak I, White PJ (2019) Plant nutrition and soil fertility: synergies for acquiring global green growth and sustainable development. P1 Soil 434:1-6

Schnurer J, Rosswall T (1982) Fluorescein diacetate hydrolysis as a measure of total microbial activity in soil and litter. App Environ Microbiol 43:1256-1261 
Scragg A (2006) Environmental Biotechnology. Oxford University Press, Oxford, UK, 2nd edition.

Silva JDC, Leal TTB, Araújo ASF, Araujo RM, Gomes RLF, Melo WJ, Singh RP (2010) Effect of different tannery sludge compost amendment rates on growth, biomass accumulation and yield responses of Capsicum plants. Waste Manag 30:1976-1980

Singh RP, Singh P, Araujo AS, Ibrahim MH, Sulaiman O (2011) Management of urban solid waste: vermicomposting a sustainable option. Resour Conserv Recycl 55:719-729

Sousa RS, Nunes LAPL, Bonifacio A, Melo WJ, Singh RP, Araujo ASF (2018) Chromium accumulation in maize and cowpea after successive applications of composted tannery sludge. Acta Sci Agron 40: e35361

Sousa RS, Santos VM, Melo WJ, Nunes LAPL, Van den Brink PJ, Araujo ASF (2017) Time-dependent effect of composted tannery sludge on the chemical and microbial properties of soil. Ecotoxicology 26:1366-1377

Srivastava V, Araújo ASF, Vaish B, Sharma B, Singh P, Singh RP (2016) Biological response of using municipal solid waste compost in agriculture as fertilizer Supplement. Rev Environ Sci Bio-Tech 15: 677-696

Ter Braak CJ, Šmilauer P (2018) Canoco Reference Manual and User's Guide: Software for Ordination (Version 5.1). Microcomputer Power, Ithaca, USA. pp 536 pp.

USEPA (1986) Test method for evaluating solid waste. USEPA, Washington, DC
Van den Brink PJ, Ter Braak CJ (1998) Multivariate analysis of stress in experimental ecosystems by principal response curves and similarity analysis. Aquatic Ecol 32:163-178

Van den Brink PJ, Ter Braak CJ (1999) Principal response curves: analysis of time-dependent multivariate responses of biological community to stress. Environ Toxicol Chem 18:138-148

Vance ED, Brookes PC, Jenkinson DS (1987) An extraction method for measuring soil microbial biomass C. Soil Biol Biochem 19:703-707

Walia M, Goyal S (2010) Effect of heavy metal contaminated sewage sludge on soil microbiological properties and growth of Indian mustard. Arch Agr Soil Sci 56:563-574

Williams DA (1972) The comparison of several dose levels with zero dose control. Biometrics 28:519-531

Wolinska A, Stepniewska Z (2012) Dehydrogenase activity in the soil environment. In: Canuto RA (ed) Dehydrogenases. Intech, Rijeka Available at http://www.ebook3000.com/

Wyszkowska J, Kucharski J, Jastrzębska E, Hlasko A (2001) The biological properties of soil as influenced by chromium contamination. Polish J Environ Studies 10:37-42

Yeomans JC, Bremner JM (1988) A rapid and precise method for routine determination of organic carbon in soil. Comm Soil Sci Pl Anal 19: $1467-1476$

Publisher's note Springer Nature remains neutral with regard to jurisdictional claims in published maps and institutional affiliations. 